\title{
Effect of Current Ratio and Return on Equity on Dividend Payout Ratio Policy
}

\author{
Waluyo Jati \\ Universitas Pamulang \\ Email: dosen00565@unpam.ac.id
}

(Received: march 12-2020; revised: June 13-2020; published: June 30-2020)

\begin{abstract}
The purpose of this study was to determine the effect of the current ratio and return on equity on dividend payout ratios in Manufacturing Companies Engaged in the Metal Industry Sector in the Indonesia Stock Exchange in 2014-2018. The method used in this study is associative, the sample used is the 5-year financial report that has made panel data. The analysis tool uses regression, coefficient of determination and hypothesis testing. The results of the study concluded that there was a significant effect between the current ratio to the dividend payout ratio with a determination of $35.4 \%$ and the hypothesis test of significance of $0,000<0.05$. There is a significant effect between return on equity on dividend payout ratio with a determination of $36.5 \%$ and the hypothesis test of significance $0,000<0.05$. There is a significant simultaneous effect between the current ratio and return on equity to the dividend payout ratio with a determination of $52.0 \%$ and the hypothesis test of significance $0,000<0.05$.
\end{abstract}

Keywords: Current ratio; return on equity; current ratio; dividen payout ratio

\section{INTRODUCTION}

The establishment of a company must have clear objectives (Assauri, 2008; Mulyanti, 2016; Sudana, 2011). There are several things that express the purpose of the establishment of a company. The first goal is to achieve maximum profit. The second goal is to want to prosper the owners of the company or the shareholders. Whereas the third company goal is to maximize the value of the company which is reflected in its share price. The three goals of the company are actually substantially not much different, only the emphasis to be achieved by each company is different from one another (Harjito \& Martono, 2008).

Company value can provide maximum shareholder prosperity if the share price increases. The higher the share price of a company, the higher the prosperity of shareholders. Enterprise Value (EV) or also known as firm value (company value) is an important concept for investors, because it is an indicator for the market to assess the company as a whole (Hoyt \& Liebenberg, 2011; Teece, 2010). (Kusumadilaga, 2010) states that the value of the company is the price that prospective buyers are willing to pay if the company is sold. Company value is a reflection of the addition of the amount of company equity with company debt (Waryanto, 2019).

There are several factors that affect company value, namely: funding decisions, dividend policies, investment decisions, capital structure, company growth, company size (Anjasari \& Andriati, 2016; Nofrita, 2013; Puspaningrum, 2017). Some of these factors have a relationship and influence on the value of the company that is inconsistent. The value of a company is the value of future earnings that are expected to be recalculated with the right interest rates 


\author{
$64 \mid$ Jurnal Ilmiah Ilmu Administrasi Publik: Jurnal Pemikiran dan Penelitian Administrasi Publik \\ Volume 10 Number 1, January- june 2020. Page 63-74
}

(Clementin \& Priyadi, 2016; Solikahan, Ratnawati, \& Djawahir, 2013; Wardani \& Hermuningsih, 2011)

One factor that supports investor confidence is their perception of the fairness of the price of securities (Bruno, 2019; Septyato \& Adhikara, 2013). Under such circumstances, capital markets are said to be of informational efficiency. The capital market is said to be informational efficiency if the price of the securities reflects all relevant information. Incorrect and incorrect information will certainly mislead investors in investing in securities, so this can be detrimental to investors. The faster and more accurate information reaches prospective investors and is reflected in the share price, the more efficient the capital market is (Darmadji \& Fakhruddin, 2012; Fahmi, 2014; Tandelilin, 2010)

The company's financial performance is one of the factors seen by potential investors to determine stock investment (Fachrudin, 2011; Faisal, Samben, \& Pattisahusiwa, 2018; Kasmir, 2014). For a company, maintaining and improving financial performance is a must so that the shares still exist and remain in demand by investors. The financial statements issued by the company are a reflection of the company's financial performance. Financial statements are the end of the accounting process with the aim to provide financial information that can explain the condition of the company in a period. The financial information has a function as a means of information, a tool for management accountability to the owner of the company, a depiction of indicators of the company's success and as a material for consideration in decision making (Harahap, 2010). Capital market players often use this information as a benchmark or guideline in conducting transactions in the sale and purchase of shares of a company.

Measurement of company performance is one of the indicators used by investors to assess a company from the market price of these shares on the Indonesian stock exchange. The better the company's performance, the higher the returns that will be obtained by investors. Generally investors will look for companies that have the best performance and invest their capital in these companies. It is said that the company's capital acquisition and company value will increase if the company has a good reputation reflected in its financial statements. (Horne, James C. Van and Wachowicz, 2012) stated that the measurement of financial performance includes the results of the calculation of financial ratios based on the company's financial statements that are published and have been audited by public accountants. These ratios are designed to help the analysis or investors in evaluating a company based on its financial statements.

The use of financial information provided by a company is usually an analyst or investor will calculate financial ratios that include liquidity ratios, leverage, activity and profitability of the company for the basis of consideration in investment decisions. In this study using liquidity ratios, leverage and profitability (Riyanto, 2008).

Liquidity illustrates the ability of a company to meet its financial obligations which must immediately be fulfilled (Faisal et al., 2018; Ginting, 2018; Suandy, 2011). Liquidity will affect the size of the dividends paid to shareholders. Dividends are cash outflows, the greater the amount of cash available, the better the company's liquidity is considered, the greater the company's ability to pay dividends (Harjito \& Martono, 2008). A high level of liquidity will indicate that the company is in good condition so that it will increase demand for shares and will certainly increase share prices. 
Waluyo Jati; Effect of Current Ratio and Return on Equity on Dividend Payout Ratio Policy| 65

Profitability measures the company's ability to generate profits. The profitability ratio in this study is represented by return on equity (ROE). This ratio is a ratio that shows the rate of return obtained by the owner or shareholder of investment in the company. ROE compares the amount of net income to common stock equity. The higher ROE indicates that the higher the rate of return on investment made and the lower the ROE of a company, the rate of return will be lower too. A prospective investor needs to look at the ROE of a company before deciding to make an investment in order to know how much will be generated from the investment he made (Sitepu, 2010). The higher the level of profits obtained, the company's ability to pay dividends will also be higher and the company's stock price will increase (Deitiana, 2011; Mayogi \& Fidiana, 2016; Prihatinah \& Kusuma, 2012). The following is the development of current ratio and return on assets for the 2014-2018 period.

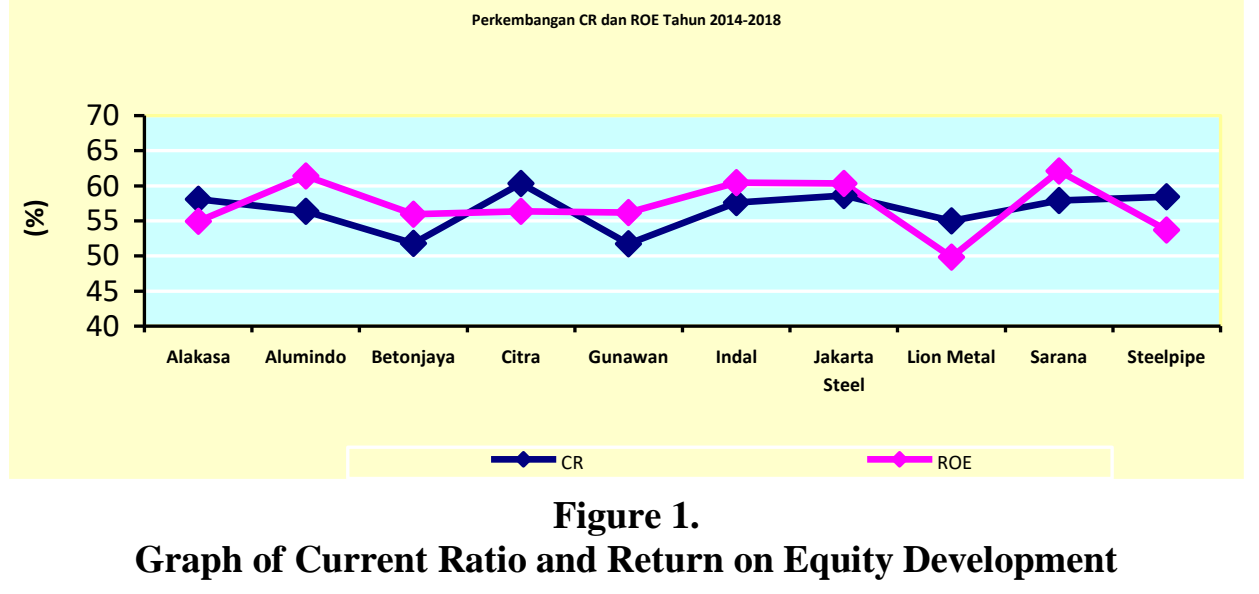

Figure 1 shows that during 2014-2018 the growth of the ability of manufacturing companies in the metal industry sector on the Indonesia Stock Exchange to pay debts (current ratio) on average experienced a fluctuating development. the highest percentage of achieving current ratio reached $60.36 \%$, while the lowest achievement reached $51.82 \%$. Similar conditions also occurred in the highest percentage of Return on Equity (ROE) reaching 62.14\%, while achieving the lowest percentage of Return on Equity (ROE) rate reaching 49.85\%.

The size of the dividend paid to shareholders depends on the dividend policy of each company and is based on various factors. According to (Gitman, Juchau, \& Flanagan, 2015) the factors that influence a company's dividend policy are debt covenants, liquidity, cash position, prospects for company growth and control powers of shareholders who own the majority of the company's shares.

Dividend policy as a moderating variable influences financial performance on firm value, this is because dividend policy is the center of attention of many parties such as shareholders, creditors, and other external parties who have an interest in information released by the company (Azis, 2017; Indriani, Susilawati, \& Purwanto, 2016; Sukirni, 2012; Welas \& Nugroho, 2019). Dividends have or contain information as a condition of the company's prospects. The greater the dividends distributed to shareholders, the company's performance will be considered better, and in the end the valuation of the company reflected through stock prices will be better too (Rozeff \& Zaman, 1988). 


\author{
66| Jurnal Ilmiah Ilmu Administrasi Publik: Jurnal Pemikiran dan Penelitian Administrasi Publik \\ Volume io Number 1, January- june 2020. Page 63-74
}

Several studies have developed and tested various models to explain dividend behavior. A survey of head office managers and investors was conducted to determine the views of some of the researchers regarding dividends. Understanding the manager's beliefs involved in determining dividend policy might contribute to understanding why companies pay cash dividends. The research conducted by Baker and Powell also contributed to survey research on dividend policy.

The use of a variable dividend payout ratio can represent a dividend policy because it is essentially determining the portion of profits to be distributed to shareholders, and which will be retained as part of retained earnings. Siregar (2010) in his research on the effect of financial performance on stock prices concluded that ROE and DER partially and simultaneously had a significant effect on stock prices. Susilo (2009) in his research using the variable ROE, has a significant influence on changes in stock prices. Siregar Research (2010).

Based on this background, in this discussion the researcher took the title "Influence of Current Ratio and Return on Equity on Dividend Payout Ratio in Metal Manufacturing Sector Manufacturing Companies in the Indonesia Stock Exchange"

\title{
METHOD
}

The type of data used is quantitative with primary data sources by distributing questionnaires which are then carried out tabulation and feasibility analysis as well as secondary data from various scientific literature. The population in this study were 10 manufacturing companies in the metal industry sector on the Indonesia Stock Exchange. The sample in this study 7 years the company's financial statements that have been made panel data.

\section{RESULT AND DISCUSSION}

Dividend policy concerns the use of profits that are the rights of shareholders. Basically, these profits can be divided as dividends or retained for reinvestment in the company. If the company chooses to distribute profits as dividends, it will reduce retained earnings and then reduce the total internal source of funds. Dividend policy is very important because it affects the company's investment opportunities, stock prices, financial structure, funding flows and liquidity positions.

\section{Descriptive Analysis}

In this study there were 10 companies which were used as survey objects namely:

\section{Table 1}

Metal Industry Sector Manufacturing Company on the IDX

\begin{tabular}{cll}
\hline No & \multicolumn{1}{c}{ Company Code } & \multicolumn{1}{c}{ Issuer Company } \\
\hline 1 & ALKA & PT. Alakasa Industrindo, Tbk \\
2 & ALMI & PT. Alumindo Light Metal Industry, Tbk \\
3 & BTON & PT. Betonjaya Manunggal, Tbk \\
4 & CTBN & PT. Citra Tubindo, Tbk
\end{tabular}




\begin{tabular}{cll}
\hline No & \multicolumn{1}{c}{ Company Code } & \multicolumn{1}{c}{ Issuer Company } \\
\hline 5 & GDST & PT. Gunawan Dianjaya Steel, Tbk \\
6 & INAI & PT. Indal Aluminium Industry, Tbk \\
7 & JKSW & PT. Jakarta Kyoei Steel Works, Tbk \\
8 & LION & PT. Lion Metal Works, Tbk \\
9 & BAJA & PT. Saranacentral Bajatama, Tbk \\
10 & ISSP & PT. Steel Pipe Industry of Indonesia, Tbk \\
\hline
\end{tabular}

Based on calculations made by panel data, the following descriptive data related to the development of the cuirrent ratio, return on assets and dividend payout ratio, can be seen in table 2.

Table 2

\section{Descriptive Statistics}

\section{Descriptive Statistics}

\begin{tabular}{lr|r|r|r|r}
\hline & N & Minimum & Maximum & Mean & Std. Deviation \\
\hline Current Ratio (CR) & 50 & 34.16 & 71.18 & 56.5944 & 8.19248 \\
\hline Return on Equity (ROE) & 50 & 31.22 & 67.72 & 57.1434 & 7.92897 \\
\hline $\begin{array}{l}\text { Dividen Payout Ratio } \\
\text { (DPR) }\end{array}$ & 50 & 42.64 & 71.18 & 58.7450 & 7.49578 \\
\hline Valid N (listwise) & 50 & & & & \\
\hline
\end{tabular}

Based on the data table above the current ratio, return on equity and dividend payout ratio during the period of 2014-2018 showed a fluctuating change. Current ratio data obtained a minimum percentage of $34.16 \%$ and a maximum percentage obtained of $71.18 \%$ with a mean score of $56.6 \%$ and a Standard Deviation of $8.19 \%$. Return on equity data obtained a minimum percentage of $31.22 \%$ and a maximum percentage of $67.72 \%$ with a mean score of $57.2 \%$ and a standard deviation of $7.92 \%$. Payout ratio dividend data obtained a minimum percentage of $42.64 \%$ and a maximum percentage of $71.18 \%$ with a mean score of $58.74 \%$ and a standard deviation of $7.49 \%$.

\section{Multiple Regression Analysis}

Regression and correlation analysis is used to measure the effect and relationship between the current ratio (CR) and return on equity (ROE) to the dividend payout ratio (DPR). The test results are as follows: 
68| Jurnal Ilmiah Ilmu Administrasi Publik: Jurnal Pemikiran dan Penelitian Administrasi Publik Volume 1o Number 1, January- june 2020. Page 63-74

Table 3

Results of Multiple Current Regression (CR) and Return on Equity (ROE) with Dividend Payout Ratio (DPR)

\begin{tabular}{|c|c|c|c|c|c|}
\hline \multirow[b]{3}{*}{ Model } & \multicolumn{2}{|c|}{ Coefficients $^{\mathrm{a}}$} & \multirow{3}{*}{$\begin{array}{l}\text { Standardized } \\
\text { Coefficients } \\
\text { Beta }\end{array}$} & \multirow[b]{3}{*}{$\mathrm{t}$} & \multirow[b]{3}{*}{ Sig. } \\
\hline & \multicolumn{2}{|c|}{$\begin{array}{l}\text { Unstandardized } \\
\text { Coefficients }\end{array}$} & & & \\
\hline & B & Std. Error & & & \\
\hline $1 \quad$ (Constant) & 12.883 & 6.477 & & 1.989 & .053 \\
\hline Current Ratio (CR) & .390 & .100 & .426 & 3.889 & .000 \\
\hline Return on equity (ROE) & .417 & .103 & .441 & 4.027 & .000 \\
\hline
\end{tabular}

a. Dependent Variable: Dividen Payout Ratio (DPR)

Obtained a regression equation $\mathrm{Y}=12,883+0,390 \mathrm{X} 1+0,417 \mathrm{X} 2$. From the results above, it shows that the influence between the current ratio and return on equity with the company's dividend payout ratio shows that there is a positive effect. 12,883 points, meaning that if the current ratio (X1) and return on equity $(\mathrm{X} 2)=0$ or constant, then the company's payout ratio will be worth $12.883 \%$. 0.390 points, meaning that if the current ratio (X1) has increased by one unit, while return on equity (X2) is constant or constant, then the dividend payout ratio (Y) will increase by $0.390 \%$. 0.417 points, if the return on equity (X2) increases by one unit, while the current ratio (X1) is constant or constant, then the dividend payout ratio (Y) will increase by $0.417 \%$.

\section{Correlation Coefficient Analysis}

For further correlation analysis is intended to determine the relationship between variables. In analyzing the relationship between the variable current ratio (X1) and return on equity (X3) to the dividend payout ratio (Y), researchers used data processing with SPSS version 25 , namely in table 4 .

Table 4

Results of Correlation Coefficient Test for Current Ratio (X1), Return on Equity (X2) to Dividend Payout Ratio (Y)

\begin{tabular}{|c|c|c|c|c|}
\hline \multicolumn{5}{|c|}{ Model Summary $^{\mathbf{b}}$} \\
\hline Model & $\mathrm{R}$ & R Square & Adjusted R Square & $\begin{array}{l}\text { Std. Error of the } \\
\text { Estimate }\end{array}$ \\
\hline 1 & $.721^{\mathrm{a}}$ & .52 & .499 & 5.30454 \\
\hline
\end{tabular}

a. Predictors: (Constant), Return on Equity (ROE), Current Ratio (CR)

b. Dependent Variable: Dividen Payout Ratio (DPR)

Obtained the correlation coefficient is 0.721 and according to the provisions, the two variables have a positive relationship because the numbers obtained are positive. This means 
Waluyo Jati; Effect of Current Ratio and Return on Equity on Dividend Payout Ratio Policy $\mid 69$

that the Current ratio (X1) and Return on Equity (X2) have a strong influence on the dividend payout ratio (Y).

\section{Analysis of the Coefficient of Determination}

Determination coefficient $(\mathrm{Kd})$ is used to find out how much influence between the independent variables on the dependent variable.

Table 5

Results of Current Ratio (X1) Determination Coefficient on Dividend Payout Ratio (Y)

Model Summary

\begin{tabular}{lr|r|r|r}
\hline Model & & & \multicolumn{2}{c}{$\begin{array}{c}\text { Std. Error of the } \\
\text { Estimate }\end{array}$} \\
\hline 1 & $\mathrm{R}$ & R Square & Adjusted R Square & \multicolumn{2}{c}{. } \\
\hline
\end{tabular}

a. Predictors: (Constant), Current Ratio (CR)

Obtained a coefficient of determination of 0.354 , it can be concluded that the Current ratio (X1) affects the dividend payout ratio (Y) of $35.4 \%$.

Table 6

Coefficient Results Determination of Return on Equity (X2) on Dividend Payout Ratio (Y)

Model Summary

\begin{tabular}{lr|r|r|r}
\hline Model & R & R Square & \multicolumn{1}{c}{$\begin{array}{c}\text { Adjusted R } \\
\text { Square }\end{array}$} & \multicolumn{1}{c}{ Std. Error of the Estimate } \\
\hline 1 & $.604^{\mathrm{a}}$ & .365 & .352 & 6.03490 \\
\hline
\end{tabular}

a. Predictors: (Constant), Return on Equity (ROE)

Obtained a coefficient of determination of 0.365 , it can be concluded that Return on equity (X2) affects the dividend payout ratio (Y) of $36.5 \%$.

Table 7

Coefficient Results Simultaneous Determination of Current Ratio (X1) and Return on Equity (X2) on Dividend Payout Ratio (Y) Model Summary ${ }^{\mathbf{b}}$

\begin{tabular}{lrr|rr|r}
\hline Model & & \multicolumn{2}{|c|}{$\begin{array}{c}\text { Adjusted R } \\
\text { Square }\end{array}$} & Std. Error of the Estimate \\
\hline 1 & $\mathrm{R}$ & \multicolumn{2}{|c|}{ R Square } & \multicolumn{2}{|c|}{ Squ } \\
\hline
\end{tabular}

a. Predictors: (Constant), Return on Equity (ROE), Current Ratio (CR)

b. Dependent Variable: Dividen Payout Ratio (DPR)

Obtained a coefficient of determination of 0.520 , it can be concluded that the Current ratio (X1) and Return on equity (X2) affect the dividend payout ratio (Y) of $52.0 \%$ while the remaining $48.0 \%$ is influenced by other factors 
$70 \mid$ Jurnal Ilmiah Ilmu Administrasi Publik: Jurnal Pemikiran dan Penelitian Administrasi Publik Volume 1o Number 1, January- june 2020. Page 63-74

\section{Hypothesis test}

To test the effect or relationship between the variable Current ratio (X1) and Return on equity (X2) can be done with a statistical test $t$ (partial test). The results are as follows:

\section{Table 8}

T Test Results Variable Current ratio (X1)

\section{Coefficients $^{\mathrm{a}}$}

\begin{tabular}{|c|c|c|c|c|c|}
\hline \multirow[b]{2}{*}{ Model } & \multicolumn{2}{|c|}{$\begin{array}{l}\text { Unstandardized } \\
\text { Coefficients }\end{array}$} & \multirow{2}{*}{$\begin{array}{c}\text { Standardized } \\
\text { Coefficients } \\
\text { Beta }\end{array}$} & \multirow[b]{2}{*}{$\mathrm{t}$} & \multirow[b]{2}{*}{ Sig. } \\
\hline & $\mathrm{B}$ & Std. Error & & & \\
\hline $\begin{array}{ll}1 & \text { (Constant) }\end{array}$ & 27.940 & 6.069 & & 4.604 & .000 \\
\hline Current Ratio (CR) & .544 & .106 & .595 & 5.128 & .000 \\
\hline
\end{tabular}

a. Dependent Variable: Dividen Payout Ratio (DPR)

From the test results in the table above, a significance value of $0.000<0.05$ is obtained. Thus the hypothesis proposed that there is a significant effect between the current ratio to the dividend payout ratio, is accepted.

Table 9

T Test Results Variable Return on Equity (X2)

\section{Coefficients}

\begin{tabular}{|c|c|c|c|c|c|}
\hline \multirow[b]{2}{*}{ Model } & \multicolumn{2}{|c|}{$\begin{array}{l}\text { Unstandardized } \\
\text { Coefficients }\end{array}$} & \multirow{2}{*}{$\begin{array}{c}\text { Standardized } \\
\text { Coefficients } \\
\text { Beta }\end{array}$} & \multirow[b]{2}{*}{$\mathrm{t}$} & \multirow[b]{2}{*}{ Sig. } \\
\hline & $\mathrm{B}$ & Std. Error & & & \\
\hline $\begin{array}{ll}1 & \text { (Constant })\end{array}$ & 26.107 & 6.272 & & 4.163 & .000 \\
\hline Return on Equity (ROE) & .571 & .109 & .604 & 5.253 & .000 \\
\hline
\end{tabular}

a. Dependent Variable: Dividen Payout Ratio (DPR)

From the test results in the table above, a significance value of $0.000<0.05$ is obtained. Thus the hypothesis proposed that there is a significant effect between return on equity to the dividend payout ratio, is accepted. To test the effect of the variable Current ratio (X1) and Return on equity (X2) together on the Dividend payout ratio (Y) can be done with a statistical test $\mathrm{F}$ (simultaneous test). The results can be seen in table 10 . 
Table 10

Results of Simultaneous F Testing Data Processing

\begin{tabular}{|c|c|c|c|c|c|c|}
\hline \multicolumn{7}{|c|}{ ANOVA $^{a}$} \\
\hline Model & & $\begin{array}{l}\text { Sum of } \\
\text { Squares }\end{array}$ & $\mathrm{df}$ & Mean Square & $\mathrm{F}$ & Sig. \\
\hline \multirow[t]{3}{*}{1} & Regression & 1430.653 & 2 & 715.326 & 25.422 & $.000^{\mathrm{b}}$ \\
\hline & Residual & 1322.494 & 47 & 28.138 & & \\
\hline & Total & 2753.147 & 49 & & & \\
\hline
\end{tabular}

a. Dependent Variable: Dividen Payout Ratio (DPR)

b. Predictors: (Constant), Return on Equity (ROE), Current Ratio (CR)

The test results in the table above, obtained a significance value of $0,000<0.05$. Thus the hypothesis proposed that there is a significant effect between return on equity and return on equity simultaneously on dividend payout ratios, is accepted.

\section{CONCLUSION}

Based on the results of the study it can be seen that there is a significant influence between the current ratio to the dividend payout ratio with a contribution of $35.4 \%$. Hypothesis testing obtained significance $0,000<0.05$. There is a significant effect between return on equity to the dividend payout ratio with the contribution of influence of $36.5 \%$. Hypothesis testing obtained significance $0,000<0.05$. There is a significant simultaneous effect between the current ratio and return on equity to the dividend payout ratio with a correlation coefficient of 0.721 or strong with a value of determination of 52.0\%. Hypothesis testing obtained significance $0,000<0.05$.

\section{REFERENCES}

Anjasari, S. P., \& Andriati, N. H. (2016). Pengaruh Tata Kelola Perusahaan Dan Kinerja Lingkungan Terhadap Nilai Perusahaan. Jurnal Akuntansi Dan Keuangan.

Assauri, S. (2008). Manajemen Produksi dan Operasi. Jakarta: Lembaga Penerbit Fakultas Ekonomi Universitas Indonesia.

Azis, R. Y. (2017). Pengaruh Keputusan Investasi, Kebijakan Dividen, Dan Kebijakan Hutang Terhadap Nilai Perusahaan Manufaktur Yang Terdaftar Di BEI. Skripsi.

Bruno, L. (2019). Dasar-Dasar Teori Portofolio Dan Analisis Sekuritas. Journal of Chemical Information and Modeling. https://doi.org/10.1017/CBO9781107415324.004

Clementin, F. S., \& Priyadi, M. P. (2016). Pengaruh Keputusan Investasi, Pendanaan, Kebijakan Dividen dan Profitabilitas Terhadap Nilai Perusahaan. Jurnal Ilmu Dan Riset Akuntansi.

Darmadji, T., \& Fakhruddin, H. M. (2012). Pasar Modal Di Indonesia. In Salemba Empat.

Deitiana, T. (2011). Pengaruh Rasio Keuangan, Pertumbuhan Penjualan Dan Dividen Terhadap Harga Saham. Jurnal Bisnis Dan Akuntansi. 
72 |Jurnal Ilmiah Ilmu Administrasi Publik: Jurnal Pemikiran dan Penelitian Administrasi Publik Volume 10 Number 1, January- june 2020. Page 63-74

Fachrudin, K. A. (2011). Analisis Pengaruh Struktur Modal, Ukuran Perusahaan, dan Agency Cost Terhadap Kinerja Perusahaan. Jurnal Akuntansi Dan Keuangan. https://doi.org/10.9744/jak.13.1.37-46

Fahmi, I. (2014). Manajemen Keuangan Perusahaan dan Pasar Modal. Manajemen Keuangan Perusahaan Dan Pasar Modal.

Faisal, A., Samben, R., \& Pattisahusiwa, S. (2018). Analisis kinerja keuangan. KINERJA. https://doi.org/10.29264/jkin.v14i1.2444

Febriana, E., Djumahir, \& Djawahir, A. H. (2016). Kepemilikan Saham Manajerial dan Profitabilitas Terhadap Nilai Perusahaan (Studi pada Perusahaan Manufaktur yang Terdaftar di BEI Pada 2011-2013). Jurnal Ekonomi Bisnis.

Ginting, S. (2018). Pengaruh Likuiditas, Profitabilitas. Dan Leverage Terhadap Kebijakan Deviden Pada Perusahaan Lq45 Yang Terdaftar Di Bursa Efek Indonesia Periode 20122016. Jwem Stie Mikroskil.

Gitman, L. J., Juchau, R., \& Flanagan, J. (2015). Principles of managerial finance. Pearson Higher Education AU.

Harjito, D. ., \& Martono, S. . (2008). Manajemen keuangan edisi 2. In Ekonisia.

Horne, James C. Van dan Wachowicz, J. M. (2012). Prinsip-prinsip Manajemen Keuangan. Edisi 13. Jakarta: Salemba Empat. https://doi.org/10.1016/j.neuroimage.2007.11.048

Hoyt, R. E., \& Liebenberg, A. P. (2011). The Value of Enterprise Risk Management. Journal of Risk and Insurance. https://doi.org/10.1111/j.1539-6975.2011.01413.x

Indriani, W., Susilawati, R., \& Purwanto, N. (2016). Pengaruh Kepemilikan Manajerial Dan Kinerja Keuangan Terhadap Kebijakan Dividen Pada Perusahaan Manufaktur Yang Terdaftar Di Bursa Efek Indonesia Tahun 2012-2014. Jurnal Riset Mahasiswa Akuntansi Unikama.

Kasmir. (2014). Laporan Keuangan Bank. Manajemen Perbankan.

Kurniawan, I. G. E., \& Asmara Putra, I. N. W. (2019). Pengaruh Profitabilitas, Kebijakan Utang, dan Kebijakan Dividen Terhadap Nilai Perusahaan. E-Jurnal Akuntansi. https://doi.org/10.24843/eja.2019.v28.i03.p10

Kusumadilaga, R. (2010). Pengaruh Corporate Social Responsibility Terhadap Nilai Perusahaan Dengan Profitabilitas Sebagai Variabel Moderating (Studi Empiris Perusahaan Manufaktur Yang Terdaftar di Bursa Efek Indonesia).

Mayogi, D. G., \& Fidiana. (2016). Pengaruh Profitabilitas, Kebijakan Deviden Dan Kebijakan Deviden Terhadap Nilai Perusahaan. Jurnal Ilmu Dan Riset Akuntansi.

Mulyanti, D. (2016). Manajemen Keuangan Perusahaan. Jurnal Ilmiah Akuntansi.

Nofrita, R. (2013). Pengaruh Profitabilitas terhadap Nilai Perusahaan dengan Kebijakan Deviden sebagai Variabel Intervening. Jurnal Akuntansi. 
Prihatinah, D., \& Kusuma, P. A. (2012). Pengaruh Return On Investment, Earning per Share, dan Dividen per Share terhada Harga Saham Perusahaan Pertambangan yang Terdaftar di BEI Periode 2008-2010. Jurnal Nominal. https://doi.org/10.1007/s13398-014-0173-7.2

Puspaningrum, Y. (2017). Pengaruh Corporate Social Responsibility Dan Kepemilikan Manajerial Terhadap Nilai Perusahaan Dengan Profitabilitas Dan Ukuran Perusahaan Sebagai Variabel Moderating (Studi Empiris Pada Perusahaan Pertambangan Di Bursa Efek Indonesia). Jurnal Profita.

Riyanto. (2008). Dasar dasar pembelajaran perusahaan. In Dasar dasar pembelajaran perusahaan. https://doi.org/10.1128/MCB.4.6.1134

Rozeff, M. S., \& Zaman, M. A. (1988). Market Efficiency and Insider Trading: New Evidence. The Journal of Business. https://doi.org/10.1086/296418

Septyato, D., \& Adhikara, A. (2013). Perilaku Investor Individu dalam Pengambilan Keputusan Investasi Sekuritas di Bursa Efek Indonesia (BEI). Journal \& Proceeding FEB UNSOED.

Sitepu, C. N. (2010). Pengaruh Kinerja Keuangan Terhadap Harga Saham Pada Perusahaan Industri Makanan dan Minuman Yang Terdaftar di Bursa Efek Indonesia (BEI).

Solikahan, E. Z., Ratnawati, K., \& Djawahir, A. H. (2013). Pengaruh Leverage dan Investasi terhadap Nilai Perusahaan ( Studi pada Perusahaan Makanan dan Minuman di Bursa Efek Indonesia ). Jurnal Aplikasi Manajemen.

Suandy, E. (2011). Perencanaan Pajak. In Perencanaan Pajak (Edisi 5).

Sudana, I. M. (2011). Manajemen Keuangan Perusahaan Teori \& Praktik. In Erlangga. https://doi.org/10.1145/2505515.2507827

Sukirni, D. (2012). Kepemilikan Manajerial, Kepemilikan Institusional, Kebijakan Dividen Dan Kebijakan Hutang. Accounting Analysis Journal.

Tandelilin, E. (2010). Dasar-dasar Manajemen Investasi. In Keuangan.

Teece, D. J. (2010). Business models, business strategy and innovation. Long Range Planning. https://doi.org/10.1016/j.lrp.2009.07.003

Wardani, D. K., \& Hermuningsih, S. (2011). Pengaruh Struktur Kepemilikan terhadap Nilai Perusahaan dengan Kinerja Keuangan dan Kebijakan Hutang sebagai Variabel Intervening. Jurnal Siasat Bisnis. https://doi.org/10.20885/jsb.vol15.iss1.art3

Waryanto, H. (2019). The Influence of Return on Equity Ratio and Debt to Equity Ratio to Price to Earning Ratio in Galvalum Companies Listed on the Indonesia Stock Exchange for the 2014-2018 Period. PINISI Discretion Review, 3(2), 185-192.

Welas, W., \& Nugroho, S. Y. (2019). Analisis Faktor-Faktor Yang Mempengaruhi Kebijakan Dividen. AKURASI: Jurnal Riset Akuntansi Dan Keuangan. https://doi.org/10.36407/akurasi.v1i1.65 
74 Jurnal Ilmiah Ilmu Administrasi Publik: Jurnal Pemikiran dan Penelitian Administrasi Publik Volume io Number 1, January- june 2020. Page 63-74 